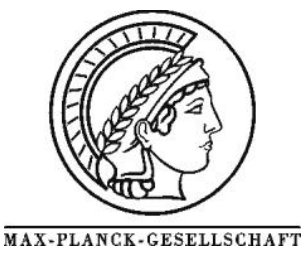

\title{
2.3.9. Oxo-Anion Modified Oxides
}

\author{
FRIEDERIKE C. JENTOFT
}

\subsubsection{Introduction}

\subsection{Classification}

In the interaction of two or more catalyst components, two extremes can be found: The formation of a compound or a solid solution constitutes the most intimate and homogeneous type of interaction, while the formation of a non-wetting surface species on an inert support can be seen as the minimal type of interaction. For supported catalysts, the goal is usually the dispersion of the active species; the structural integrity of the support remains unchanged although strong interactions may occur at the interface of the support and the dispersed phase (see Chapter 3.2.5). In this sense, anion-modified oxides such as sulfated or tungstated zirconia or sulfated titania could simply be understood as supported systems, specifically as mounted acids. In a typical preparation route, however, the second componentsulfate, tungstate - is added to the precursor and is already present when the crystalline oxide is formed by thermal treatment. As a consequence, the textural and structural properties - particularly zirconia features a vivid phase chemistry — of the matrix oxide are severely influenced by the additive. If further components such as promoters are added, the situation will become more complex. Although the product might be considered a surface-functionalized oxide, the systems are characterized by a strong interaction of the functionalizing agent and the matrix, leading to a mutual directing of their structures. The final product ideally features only the matrix oxide as crystalline phase. In that, these systems are also distinguished from coprecipitated catalysts such as $\mathrm{Ni} / \mathrm{Al}_{2} \mathrm{O}_{3}$ and $\mathrm{Cu} / \mathrm{ZnO}$, which also feature precursors with intimate mixing of the components, but the final product obtained after a reduction step consists of separate phases, which are individually detectable by diffraction. Oxo-anion modified oxides can thus be viewed as a separate class of catalysts.

\subsection{Motivation for Selection of System}

The lead system discussed in this article is sulfated zirconia but other varieties of this type of catalyst, i.e. other anions and other oxides are also discussed. Sulfated zirconia was first described in a patent by Holm and Bailey in 1962 [1]. Profound interest in the system was raised through two articles by Hino and Arata who reported sulfated zirconia to be active for $n$-butane isomerization at room temperature, i.e., at conditions that thermodynamically favor the desired branched isomer [2,3]. Commercialization of sulfated zirconia by UOP has been reported [4,5], emphasizing the significance of this catalyst. Sulfated zirconia can be employed for a number of different reactions, mostly acid-catalyzed processes; examples are alkylation, condensation, etherification, acylation, esterification, nitration, and oligomerization [6].

Both components can be varied, i.e. zirconia can be mixed with other oxides [7], or other matrix oxides or mixtures thereof can be employed. Also other oxo-anions can be used. For example, sulfated $\mathrm{TiO}_{2}, \mathrm{HfO}_{2}, \mathrm{SnO}_{2}$ and $\mathrm{Fe}_{2} \mathrm{O}_{3}$ are active for the skeletal isomerization of $n$-butane to isobutane at low temperatures [8]. Sulfated $\mathrm{SiO}_{2}$ is active for the dehydration of ethanol [8]. $\mathrm{ZrO}_{2}$ combined with tungstate is a catalyst for alkane isomerization $[9,10]$ and cracking [11], $\mathrm{ZrO}_{2}$ with molybdate for conversion of hexane or benzoylation of toluene with benzoic anhydride [10] and $\mathrm{ZrO}_{2}$ with borate for benzoylation of anisole with benzoyl chloride [12]. Materials obtained by treating $\mathrm{ZrO}_{2}$ with $\mathrm{SeO}_{4}{ }^{2-}, \mathrm{TeO}_{4}{ }^{2-}$ and $\mathrm{CrO}_{4}{ }^{2-}$ are active for alkane dehydrogenation [8]. As a selection of combinations containing neither sulfate nor zirconia, tungstated $\mathrm{SnO}_{2}, \mathrm{TiO}_{2}$ and $\mathrm{Fe}_{2} \mathrm{O}_{3}$ may be named [10]; numerous other combinations can be imagined.

The activity of sulfated zirconia for butane isomerization can be further improved by orders of magnitude through adding cations of $\mathrm{Fe}$ and $\mathrm{Mn}[13,14]$, or e.g. Co or Ni [15]. Equally, tungstated zirconia can be promoted with, 
e.g., Fe [16]. In general, sulfated or tungstated zirconia catalysts deactivate rapidly $[17,18]$, but by addition of a noble metal to the catalyst and hydrogen to the feed the isomerization activity can be stabilized $[16,19,20]$ A complete catalyst thus consists of up to four types of components: the matrix oxide(s), the oxo-anion(s), promoters (optionally), and noble metal(s).

\subsubsection{Target Properties}

Three types of correlations have been made: performance and a measured or known physical quantity, performance and a preparation parameter or an observable that is characteristic of the preparation procedure, and physical quantities and a preparation parameter. The first type allows for a targeted synthesis, in the next step, the relations between physical quantities and preparation parameters must be identified.

\subsection{Structure-Activity Relationships}

Sulfated zirconia catalysts, unless noble-metal doped and operated in the presence of $\mathrm{H}_{2}$, usually do not exhibit stable performance. For any correlation, it should thus be specified if the maximum or steady state activity has been evaluated.

The phase composition of zirconia was identified as important. Zirconia appears in three polymorphs, with the monoclinic phase being the room temperature stable modification. Above $1443 \mathrm{~K}$, the tetragonal modification is preferred and beyond $2643 \mathrm{~K}$, the cubic phase becomes stable [21]. The monoclinic phase of zirconia has been reported as inactive [22], or at least a factor of 4-5 less active than tetragonal zirconia [23]. Consistent with insignificant activity of the monoclinic phase, the maximum $n$-butane isomerization conversion (or rate) was found to be proportional to the fraction of tetragonal phase $[24,25]$. However, the tetragonal phase is only a necessary but not a sufficient requirement for good catalytic activity [26], i.e. not all tetragonal materials are automatically good catalysts. Sulfated zirconia that does not exhibit a distinct diffraction pattern has been claimed to be more [27] or less [28] active than conventional sulfated zirconia.

Catalytic activity is related to the surface area, e.g. for butane isomerization [29,30], or toluene cracking [31]. For the liquid phase acylation of anisole with benzoyl chloride, the conversion was linearly related to the surface area and increased monotonously with pore diameter in the range of 4.5 to $10.5 \mathrm{~nm}$ [32].

The sulfur content is also an essential parameter. For toluene benzylation, conversion increases linearly in the range $0.01-0.023 \% \mathrm{~S} /\left(\mathrm{m}^{2} \mathrm{~g}^{-1}\right)$, this should correspond to densities of 2-4 S atoms $\mathrm{nm}^{-2}$ [33]. The conversion of methylcyclopentane however passes through a maximum at an intermediate sulfate content [34]. The $n$-butane isomerization activity of Pt-doped sulfated zirconia increases with increasing sulfur content up to a level of ca. $1 \mathrm{~S}$ atom $\mathrm{nm}^{-2}$ and then remains constant [35]. Other sources report distinct maxima in the isomerization rate of sulfated zirconia for sulfur contents of $170 \mu \mathrm{g} \mathrm{m}^{-2}$ (3 at S nm${ }^{-2}$ ) [36], or 1-2 $\mathrm{wt} \% \mathrm{~S}$ [37], or $2.6 \mathrm{wt} \% \mathrm{~S}$ [30]. In more detail, there is evidence that a disulfate surface structure $\left(\mathrm{S}_{2} \mathrm{O}_{7}{ }^{2-}\right)$ is relevant for good performance in $n$-butane isomerization, and this condensation product is only formed at high sulfate surface density upon dehydration $[38,39,40,41,42]$.

The highest butane isomerization rates per $\mathrm{m}^{2}$ are observed at a Brønsted-to-Lewis sites ratio of 1 after activation (as determined by pyridine adsorption) [36]. The Brønsted-to-Lewis sites ratio increases with increasing sulfate content. Unfortunately, the correctness of the number of Lewis sites as obtained by pyridine adsorption was questioned, because this strong nucleophile may substitute sulfate as a ligand of $\mathrm{Zr}$ ions and the Lewis acid sites will be over-determined [43]. Correlations of the reaction rate to the total number of acid sites as measured by ammonia adsorption are not always convincing, e.g. a poor correlation was obtained for an acylation reaction [44]; good correlations were observed for 2-propanol dehydration and cumene dealkylation [45]. On the other hand, the $n$-butane isomerization rate was found to be proportional to the number of Brønsted acid sites as determined by pyridine adsorption [46].

A preparative goal should thus be to maximize the fraction of tetragonal zirconia, which in the overwhelming number of papers is found more active in comparison to monoclinic or amorphous zirconia, and to maximize the surface area. Attempts have been made to simply support sulfated zirconia (or other oxo-anion modified oxides) on oxides with a higher surface area; these systems are excluded here, more information can be found in Refs. $[47,48,49,50,51]$. The target with respect to the sulfate content is less clear. There appears to be an optimum, and this goes along with the fact that Brønsted and Lewis sites are both necessary because the fraction of Brønsted sites increases with increasing sulfate content. On the other hand, a disulfate structure seems to be desirable, and such a condensed species preferably forms with increasing sulfate surface density. Furthermore, the described properties are not independent of each other due to the strong interaction between oxo-anion and matrix oxide.

\subsection{Effect of Sulfate and Other Oxo-Anions}

The sulfate content influences the structural and textural properties of the final product. While pure zirconia, depending on temperature, crystallizes into a mixture of monoclinic and tetragonal zirconia, the tetragonal phase becomes more and more predominant with increasing sulfate content [52]. No general statement can be made as to the amount of sulfate necessary to obtain solely tetragonal zirconia because the phase composition depends also strongly on the calcination conditions (vide infra). 


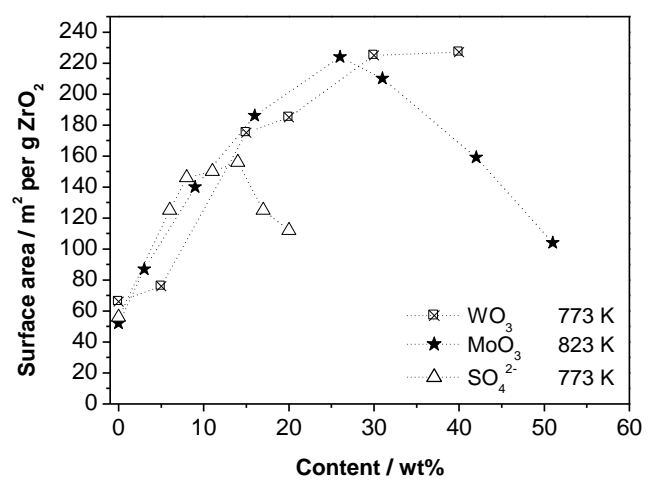

Figure 1: Surface area as a function of modifier content, with modifier type as parameter (after Ref. [54]).

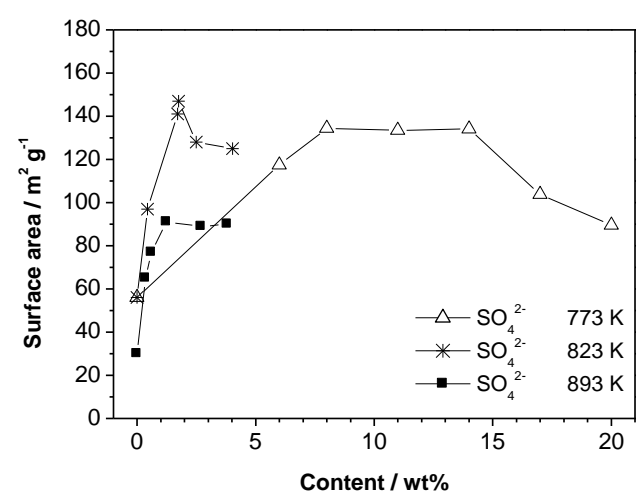

Figure 2: Surface area as a function of sulfate content, with calcination temperature as parameter (after Refs. [35,54,52]).

The surface area was found to be a linear function of the sulfate content up to about $5 \mathrm{wt} \% \mathrm{SO}_{4}{ }^{2-}$, with a slope of $30 \mathrm{~m}^{2} \mathrm{~g}^{-1}$ per wt $\% \mathrm{SO}_{4}{ }^{2-}$ for $\mathrm{ZrO}_{2}, \mathrm{TiO}_{2}$ and $\mathrm{SnO}_{2}$, and a slope of $8 \mathrm{~m}^{2} \mathrm{~g}^{-1}$ per $\mathrm{wt} \% \mathrm{SO}_{4}{ }^{2-}$ for $\mathrm{Al}_{2} \mathrm{O}_{3}$ and $\mathrm{Fe}_{2} \mathrm{O}_{3}$ [31]. The linear correlation can be interpreted in terms of stabilization of a certain area surface per sulfate group, namely $0.5 \mathrm{~nm}^{2}$ for oxides with the stoichiometry $\mathrm{MO}_{2}$ or $0.14 \mathrm{~nm}^{2}$ for the $\mathrm{M}_{2} \mathrm{O}_{3}$ type. Other studies confirm the surface area increase up to 4-6 $\mathrm{wt} \% \mathrm{SO}_{4}{ }^{2-}$; at higher contents, the data are not consistent [37,53]. Anions like sulfate, tungstate, and molybdate have the same effect, as can be seen in Fig. 1 [52,54]. The relative weights of $\mathrm{WO}_{3}, \mathrm{MoO}_{3}$, and $\mathrm{SO}_{4}{ }^{2-}$ explain the offset of the curves with respect to content. The attainable surface area, however, is considerably higher for $\mathrm{WO}_{3} / \mathrm{ZrO}_{2}$ and $\mathrm{MoO}_{3} / \mathrm{ZrO}_{2}$. For sulfated zirconia, the surface area decreases at higher calcination temperatures, and the maximum is found at lower sulfate contents, as Fig. 2 demonstrates.

At very high sulfate contents, the surface area decreases (see Fig.1), and also the size of the tetragonal crystallites increases (based on analysis of the line width with the Scherrer formula) $[55,56]$. No systematic trend in the porosity with the sulfur content could be found [52]. A maximum in the number of Brønsted sites (as measured by
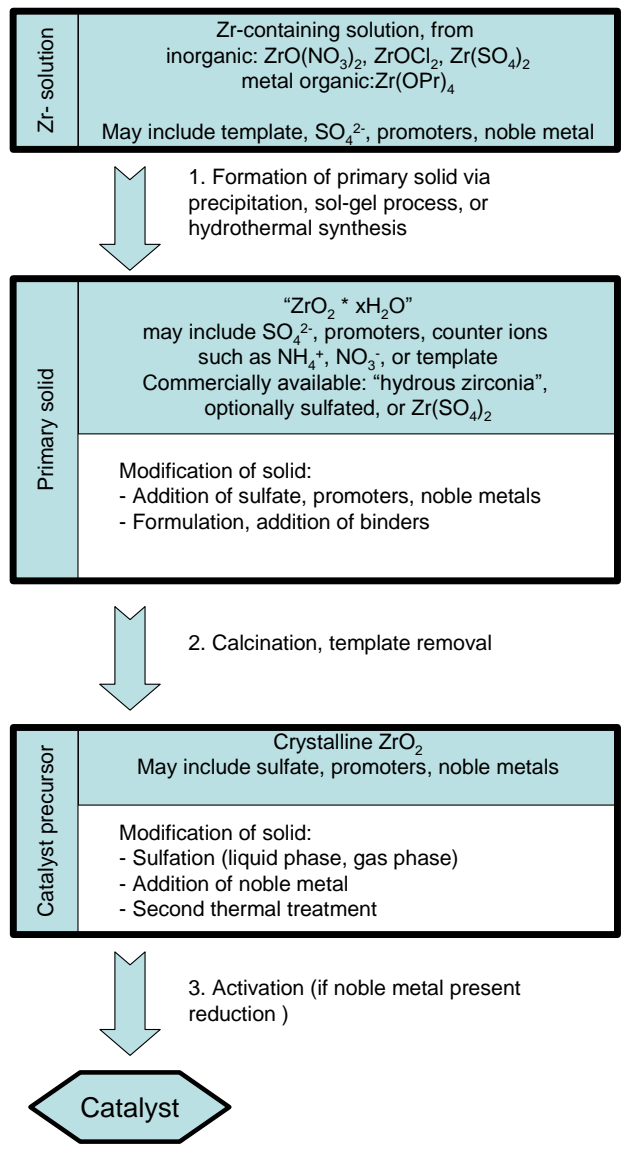

Figure 3: General preparation scheme for sulfated zirconia as an example for an oxo-anion modified oxide.

pyridine adsorption) is found at around $4 \mathrm{~S}$ atoms $\mathrm{nm}^{-2}$ [57].

A high sulfate content is desirable because the active condensed sulfate structure seems to form only when a sufficient sulfate density is reached on the surface, and further the surface area increases with sulfate content. However, very high sulfate contents have negative effects. The sulfate content can be controlled through the sulfation procedure only if it is ensured that there will be no sulfur loss during calcination.

\subsubsection{Preparation Routes}

The typical preparation route of sulfated zirconia and related materials follows the classical sequence according to IUPAC [58]: formation of a primary solid with all components, thermal treatment, and activation. The principles of preparing a precursor for the matrix oxide by precipitation or sol-gel synthesis are presented in Chapters 2.3.3 and 2.3.4. of this handbook. The procedures for dispersing noble metals are discussed in Chapter 2.4.2 However, oxoanions, promoters, and noble metals can be associated at different stages of the preparation, as can be seen in Fig. 3 . The main theme of this article is to develop an understanding for the interaction of oxide precursor, oxo-anion, and promoters during formation of the primary solid or during 
thermal treatment and for the ensuing solid state chemistry, and from this knowledge to recommend suitable compositions and preparation procedures.

\subsubsection{Formation of Primary Solid}

To produce a suitable precursor for a high surface area zirconia, the starting point is usually a zirconium species dissolved in liquid phase. The zirconium reagent can either be an inorganic salt or an organyl.

Zirconium salt solutions have a number of industrial uses $[59,60]$ and their chemistry has been studied extensively [61-73]. In general, zirconium(IV) cations have a strong tendency to hydrolyze in aqueous medium, i.e. the solutions are not stable and typically turn cloudy, making it difficult to exert control. Attempts have been made to identify the complexes that are formed in the hydrolysis reaction as well as the species that are formed in subsequent reactions. The research has focused on solutions containing anions such as chloride, nitrate, and perchlorate, which are neither strongly complexing nor bridging. A discrete tetrameric complex, $\left[\mathrm{Zr}_{4}(\mathrm{OH})_{8}\left(\mathrm{H}_{2} \mathrm{O}\right)_{16}\right]^{8+}$ is present; it can be neutralized through attachment of eight chloride ions $[62,63]$. The tetrameric complex has been found in zirconium oxychloride solutions $[64,68,71]$, in zirconium perchlorate solutions [66] and in zirconium nitrate solutions [65]. Upon increase of temperature or $\mathrm{pH}$, the tetramer will oligomerize, presumably in a first step to an octamer [64,71] of the constitution $\left[\mathrm{Zr}_{8}(\mathrm{OH})_{20}\left(\mathrm{H}_{2} \mathrm{O}\right)_{24} \mathrm{Cl}_{12}\right]$ [68] and then to higher oligomers which will finally aggregate and precipitate. At $373 \mathrm{~K}, 3-7 \mathrm{~nm}$ large primary particles were observed [67], secondary particles (aggregates of primary particles) reached 175-250 $\mathrm{nm}[70,72]$. The particle growth rate can be decreased through the addition of $\mathrm{HCl}$ [71]. Hence the precipitation chemistry can be determined by concentration, $\mathrm{pH}$, and temperature.

The chemistry of zirconium sulfate solutions is different because sulfate not only strongly complexes with zirconium [74,75] but potentially acts as bridging ligand and promotes polymerization [76,77]. While cationic or neutral complexes prevail in chloride, nitrate, and perchlorate solutions, anionic [78,79] mixed hydroxo sulfato complexes [76], also of polynuclear type, are formed in sulfate solutions. Polynuclear complexes can form through different bridging mechanisms, i.e. hydroxo bridges (formed in an "olation" reaction), oxo bridges ("oxolation"), and sulfato bridges. Sulfate-bridged complexes of the constitution $\left[\mathrm{Zr}_{\mathrm{n}}(\mathrm{OH})_{\mathrm{n}+1}\left(\mathrm{SO}_{4}\right)_{2 \mathrm{n}}\right]^{(\mathrm{n}+1)-}$ were proposed [76], or complexes of the type $\left[\mathrm{Zr}(\mathrm{OH})_{2}\left(\mathrm{SO}_{4}\right)_{\mathrm{x}}\left(\mathrm{OH}_{2}\right)_{\mathrm{y}}\right]_{\mathrm{n}}{ }^{-\mathrm{n}(2 \mathrm{x}-2)}$, which include water as a ligand [80]. Hence, it is not hydrous zirconia that is precipitated from these solutions but sulfates, and the large number of possible sulfates $[61,81,82]$, particularly basic sulfates $[61,83,84,85]$, suggests that numerous complexes of different constitution may exist in solution. Consistently, no particular species have been reported as being stable over a range of conditions in zirconium sulfate solutions. The time frame for changes in these solutions [83] indicates that equilibration is slow: Precipitation in $0.5 \mathrm{M}$ $\mathrm{Zr}\left(\mathrm{SO}_{4}\right)_{2}$ solutions was observed only after 2 weeks [86], and precipitation in $0.2 \mathrm{mM} \mathrm{Zr}\left(\mathrm{SO}_{4}\right)_{2}$ could be delayed by $10 \mathrm{~h}, 2$ days, or 4 days through dissolving the salt in 1, 2, or $4 \mathrm{mM} \mathrm{HNO}_{3}$, respectively [77]. Heating promotes hydrolysis [87]. The kinetics of formation of larger particles in zirconium sulfate solutions have been investigated, the growth was accelerated at higher temperature, higher zirconium concentration and lower acid concentration [88]. From the available data it becomes clear that not only concentration, temperature and $\mathrm{pH}$ but also aging will play a role in formation of the primary solid.

The chemistry in zirconium aqueous solutions depends strongly on the complexation with the available anions. The complexes may be either cationic or anionic, which also determines the choice of surfactant in a templated synthesis. In general, for each metal cation and each oxo-anion, their joint solution chemistry must be considered, and adding the oxo-anion during the formation of the primary solid may make a large difference for the properties of the matrix.

\subsection{Formation of Pure Hydrous Zirconia}

Precursors used for the formation of hydrous zirconia are $\mathrm{ZrOCl}_{2}$ [89], $\mathrm{ZrONO}_{3}$ [36] and zirconium alkoxides $[28,90]$. Precipitating agents are aqueous ammonia [89] and solutions of $\mathrm{KOH}$ or $\mathrm{NaOH}[91,92]$. Precipitates are of a gelatinous nature [89] and a crystalline zirconium hydroxide with a defined stoichiometry does not exist [93]. Hydrolysis of alkoxides, which are soluble in e.g. ethanol, 1propanol, isopropanol or cyclohexane [44], can be initiated by water [94,95], acids [90] or bases [33]. For other oxides, e.g. $\mathrm{TiCl}_{4}$ or $\mathrm{SnCl}_{4}$ are used as starting compounds.

The precipitation can be conducted by adding the zirconium solution to the base or by adding the base to the zirconium solution. A more dramatic effect than the method of addition has the subsequent ageing or digesting of the precipitate [89]. Fig. 4 shows how the surface area and the fraction of tetragonal phase increase with increasing digestion temperature. Moreover, the surface area correlates with the fraction of tetragonal phase. The surface area also increases with digestion time, e.g. from $48 \mathrm{~m}^{2} \mathrm{~g}^{-1}$ without digestion to $248 \mathrm{~m}^{2} \mathrm{~g}^{-1}$ after $96 \mathrm{~h}$ digestion at 373 $\mathrm{K}$ and calcination at $773 \mathrm{~K}$ [89], and the pore size distribu tion becomes narrower [28]. Digestion at $\mathrm{pH} 14(\mathrm{KOH}$ or $\mathrm{NaOH}$ ) produces materials with surface areas stable up to $773 \mathrm{~K}$, while undigested materials or those digested at $\mathrm{pH}$ 11-9.4 $\left(\mathrm{NH}_{4} \mathrm{OH}\right)$ lose surface area upon thermal treatment [91]. The nature of the acid sites is also affected, ammonia desorbs at higher temperatures from previously digested calcined zirconia, but the adsorbed amount per $\mathrm{m}^{2}$ is unaffected [92]. 


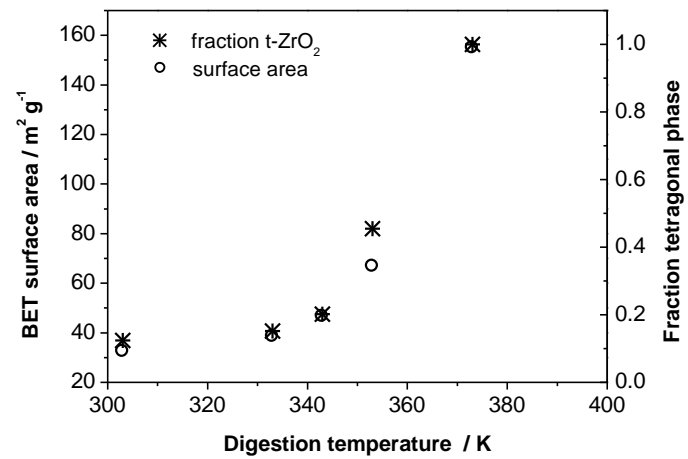

Figure 4: Surface area and fraction of tetragonal phase as a function of digestion temperature. Basic precipitation, calcination at 873 K (after Ref. [89]).

Hydrous zirconia can also be prepared via hydrolysis of zirconium alkoxides. Variations of the water/alkoxide ratio between 2-32 were found to be of minor influence for the surface area of the calcined zirconia $(773 \mathrm{~K})$ in comparison to the digestion time [95]. The zirconia surface area increases until about $200 \mathrm{~h}$ of digestion time at $\mathrm{pH}=9$, reaching values $>300 \mathrm{~m}^{2} \mathrm{~g}^{-1}$. Digestion at $\mathrm{pH}=1$ or 3 produces surface areas $<100 \mathrm{~m}^{2} \mathrm{~g}^{-1}$; in general the fraction of monoclinic phase in the calcined material $(773 \mathrm{~K})$ increases with decreasing $\mathrm{pH}$ of the suspension [28,95]. Zirconia gels can also be produced in supercritical $\mathrm{CO}_{2}$ by hydrolyzing zirconium alkoxides with acetic acid [90].

\subsection{Formation of Sulfate-Containing Hydrous Zirconia}

Sulfate can already be added during the formation of the primary solid. In a synthesis via gel formation from alkoxides, sulfate can be introduced during the gelling step $[53,96,97]$ or during peptization [98]. Tungstate can equally be co-gelled [99]. Reverse microemulsions can also be used as a synthesis medium for sulfated zirconia nanoparticles [100].

A large amount of sulfate can be incorporated into the precursor because of the ability of the sulfate to act as a bridging ligand between zirconium cations. The amount of sulfate can exceed $50 \mathrm{wt} \%$ after application of sulfuric acid for peptization following a sol-gel synthesis; leading also to sulfate contents of around $20 \mathrm{wt} \%$ after calcination at 823 K [98]. For calcination temperatures below $873 \mathrm{~K}$, samples co-gelled with sulfate exhibit higher surface areas than those sulfated afterwards with ammonium sulfate [96]. The surface and bulk sulfate concentrations increase with increasing $\mathrm{H}_{2} \mathrm{O} / \mathrm{Zr}$ ratio [101]. The drying method has been investigated, with a xerogel (regular drying) being more active in $n$-butane isomerization than an aerogel (supercritical drying) [102].

\subsection{Template-Directed Formation of Primary Solid}

Supports such as silica can been synthesized in the form of mesoporous molecular sieves [103, Chapter 2.3.6]. These materials are characterized by a very high surface area, which would be desirable also for zirconia, and can be obtained in a template-assisted hydrothermal synthesis. Surfactant molecules assemble to micelles, which direct the growth of the oxide matrix from an organometallic precursor. The surfactant is removed in a calcination step. The difficulty with zirconium is that in strongly acidic solutions, which are necessary to prevent hydrolysis, zirconium is present in the form of cations (see section 0) but the typically used surfactants are then protonated and hence assembly cannot take place [104]. A solution is the addition of sulfate to generate anionic zirconium species, but full condensation is apparently prevented and the framework may be partially destroyed when sulfate is removed by calcination. Using hexadecyltrimethyl ammonium bromide as surfactant, it was possible to obtain an MCM-41 like structure, which collapsed during calcination [105]. Treatment of the as-synthesized composite with phosphoric acid stabilizes the structure throughout calcination, with $\mathrm{S}$ and $\mathrm{P}$ contents of 1 and $10 \mathrm{wt} \%$ in the final product. By using zirconium propoxide and ammonium sulfate instead of zirconium sulfate, an ordered pore system with $\mathrm{S}$ contents of up to $8.5 \mathrm{wt} \%$ could be obtained [80]. Further procedures with $[106,107,108]$ or without [109] sulfate in the surfactant-containing synthesis mixtures have been published. The structural homogeneity and the catalytic properties of these materials vary. Inactivity in $n$-hexane isomerization was found combined with high activity for benzene alkylation with propene [106]. Lower activity in $n$ butane isomerization than for conventional tetragonal zirconia was observed for mesostructured zirconia [108], but a higher activity has also been reported [109].

\subsection{Commercially Available Precursors}

Hydrous and sulfated hydrous zirconia materials are available e.g. from MEL Chemicals or Sigma-Aldrich [110] and are frequently employed in research and application to produce sulfated zirconia catalysts $[15,111,112,113]$ Zirconium compounds contain Hf as an impurity, e.g. hydrous zirconia contains typically about $1 \mathrm{wt} \%$ Hf [112]. Also zirconium sulfate, titanium sulfate and tin sulfate can be used as precursors for the corresponding sulfated metal oxides $[31,114,115]$ 


\subsubsection{Anion-Modification of Primary Solid}

\subsection{Addition of Oxo-Anions to Primary Solid in Liquid Medium}

Different sulfating agents are used for sulfation in aqueous solution: $\mathrm{H}_{2} \mathrm{SO}_{4},\left(\mathrm{NH}_{4}\right)_{2} \mathrm{SO}_{4}, \mathrm{HSO}_{3} \mathrm{Cl}$ [116], $\left(\mathrm{NH}_{4}\right)_{2} \mathrm{~S}_{2} \mathrm{O}_{8}$ [117,118], and $\mathrm{Zr}\left(\mathrm{SO}_{4}\right)_{2}$ [119]. Procedures used are incipient wetness impregnation [35], soaking in excess impregnating solution and filtering (sometimes referred to as percolation) [52,120] soaking in excess impregnation solution and solvent evaporation [121]. Typical precursors for other oxo-anions are ammonium metatungstate $\left(\mathrm{NH}_{4}\right)_{6} \mathrm{H}_{2} \mathrm{~W}_{12} \mathrm{O}_{40} * \mathrm{H}_{2} \mathrm{O}$ [8] or ammonium metamolybdate [122].

The surface sulfur content (calculated from total content and surface area with the assumption that all sulfate is on the surface) in the calcined and reduced catalysts increases linearly with the concentration of the $\mathrm{H}_{2} \mathrm{SO}_{4}$ used in an incipient wetness procedure [35]. When an excess of acid is applied and the solid is filtered, the total sulfate content in the calcined product increases first steeply $(<0.5$ M) and then linearly with $\mathrm{H}_{2} \mathrm{SO}_{4}$ concentration $[52,123] \mathrm{A}$ similar course is found for the sulfate surface density [118]. The surface sulfate content of the calcined materials (as measured by photoelectron spectroscopy) increases initially more steeply with increasing $\mathrm{H}_{2} \mathrm{SO}_{4}$ molarity than the total sulfate content [52]. The sulfate content increases with the amount of sulfuric acid used for the impregnation [34]. More sulfate can be deposited (solvent evaporation) than adsorbed (filtration) [124].

As a natural consequence of the described dependence of the surface area on the sulfate content and the possible ways to modify the sulfate content by way of the impregnation step, the surface area correlates with the amount of sulfate applied. These correlations all show maxima in the surface area, either at an intermediate $\mathrm{H}_{2} \mathrm{SO}_{4}$ amount [34] or at intermediate concentrations, e.g. at $1 \mathrm{~N}$ $\mathrm{H}_{2} \mathrm{SO}_{4}$ [120] or 0.2-0.25 $\mathrm{M} \mathrm{H}_{2} \mathrm{SO}_{4}$ [123]. A maximum surface area at $0.5 \mathrm{~N} \mathrm{H}_{2} \mathrm{SO}_{4}$ coincides with the maximum in butane conversion [94]. The pore diameter decreases with the addition of sulfate and remains constant at about 8 $\mathrm{nm}$ for $\mathrm{H}_{2} \mathrm{SO}_{4}$ concentrations > $0.1 \mathrm{~N}$ [120]. Not only the sulfate concentration but also the $\mathrm{pH}$ plays a role: the maximum surface area is attained when hydrous zirconia is soaked in a sulfate containing solution of $\mathrm{pH}$ of 6-9, and these samples also give the maximum isobutane yield under steady state conditions [125]. The precursors, which result in different $\mathrm{pH}$ unless it is adjusted, are also important, e.g. catalysts obtained via $\mathrm{H}_{2} \mathrm{SO}_{4}$ impregnation produce higher butane conversion than those from $\mathrm{NH}_{4}\left(\mathrm{~S}_{2} \mathrm{O}_{8}\right)$ impregnation [118]. Some authors report a preference for $\mathrm{H}_{2} \mathrm{SO}_{4}$ as sulfating agent [10], others for $\left(\mathrm{NH}_{4}\right)_{2} \mathrm{SO}_{4}[6]$.

\subsection{Sulfation of Primary Solid via Gas Phase}

Treatment of zirconium hydroxide with $\mathrm{SO}_{2}$ enhances the activity for $n$-butane isomerization as much as impregnation with sulfuric acid, while treatment with $\mathrm{H}_{2} \mathrm{~S}$ or $\mathrm{SO}_{3}$ does not produce active materials [2]. Silica gel can be treated with $\mathrm{SO}_{2} \mathrm{Cl}_{2}$, which reacts with the surface $\mathrm{OH}$ groups, to attach sulfate to silica [8].

\subsection{Introduction of Oxo-Anions Using Solid Precursors}

Calcination of a kneaded mixture of hydrous zirconia and ammonium sulfate at $773 \mathrm{~K}$ produces a material active for butene double bond isomerization and benzoylation of anisole [126]. Kneading hydrous zirconia with $\mathrm{H}_{2} \mathrm{WO}_{4}$ followed by calcination yields a catalyst for pentane conversion [8].

\subsubsection{Addition of Promoters (Optional)}

\subsection{Promoters}

Of the main group elements, Al [117,127-133] and $\mathrm{Ga}[24,134]$ act as promoters of sulfated zirconia isomerization catalysts. First row transition metals such as $\mathrm{Ti}$ [127], V [127], Cr [127,135], Mn [10,15,136-138], Fe $[10,15,127,135,136,137,139-142]$, Co $[15,127,135]]$ and $\mathrm{Ni}$ $[15,127,132,135,139,143,144]$ have drawn considerable attention. $\mathrm{Nb}$ is a promoter for alkane isomerization [145]. Silver and copper in the form $\mathrm{Ag}^{0}$ and $\mathrm{Cu}^{0}$ promote the activity of sulfated zirconia for $n$-pentane isomerization [146]. $\mathrm{Ag}$ and $\mathrm{Cu}$ are also suitable as additives to tungstated zirconia [147]. Ce and other lanthanides are also promoters of sulfated zirconia [112,145].

Combinations of promoters have also been tested. Particularly the combination of $\mathrm{Fe}$ and $\mathrm{Mn}$ was studied in detail for isomerization [14,127,136,137,139,148-171] and also for cracking $[172,173,174]$ and alkylation reactions [175] because a synergy effect between the two promoters was reported. Other successful combinations include $\mathrm{Cr}-\mathrm{Fe}$ and $\mathrm{V}-\mathrm{Fe}$ [127].

\subsection{Structure-Activity Relationships}

Some relations concerning performance and promoters have been put forth. The efficacy of the first row transition metal promoters follows a trend in the periodic table, i.e. under the selected conditions, the maximum activity decreases in the order $\mathrm{Mn}>\mathrm{Fe}>\mathrm{Co}>\mathrm{Ni}>\mathrm{Zn}$ [15]. The conversion of $n$-pentane increases with decreasing ionic 


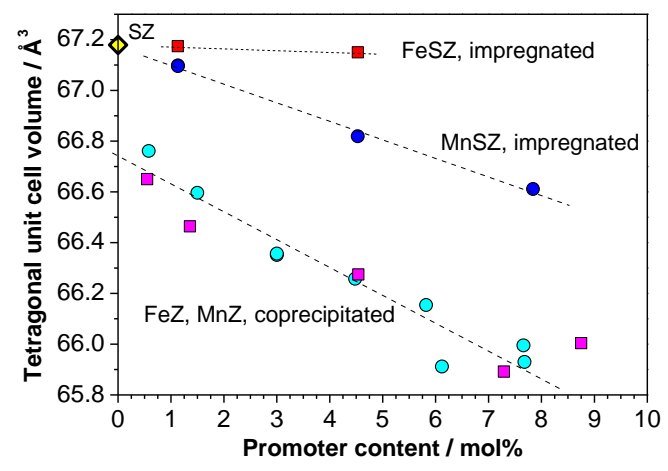

Figure 5: Tetragonal cell unit cell volume as a function of promoter content with promoter type and promoter addition method as parameters. Circles: Mn promotion, squares: Fe promotion.

radius of the promoter cation in 8 -fold coordination; this relation applies for yttrium and lanthanides [112].

The promoter content can be optimized [117,144], and, e.g., when combining group V, VI and VII elements, the sum of all promoters is ideally between 0.1 and 4.5 wt $\%$ metal [13]. The relation between conversion to isobutane and promoter content depends on the promoter type [139]. The steady state $n$-butane isomerization rate was found to increase with an increasing ratio of the lattice constant $c / a$ of the tetragonal phase for a family of $\mathrm{Fe}$ - or Mn-promoted catalysts [176].

\subsection{Effect of Promoters}

Promoters such as $\mathrm{Mn}$ or Fe stabilize the desired tetragonal phase of zirconia, and at high content the cubic phase [113]. The stabilization of the high temperature phases is a result of the incorporation of the promoter cations into the zirconia lattice [113]. This phenomenon is well known for ions of e.g. $\mathrm{Y}, \mathrm{Ca}$, or $\mathrm{Mg}$; because of its wide application as a ceramic material, yttria-stabilized zirconia has been studied extensively [177]. Many cations can be dissolved in the zirconia lattice [178-181]. The lattice parameters of the stabilized tetragonal or cubic phase vary depending on promoter type and content. The lattice may contract or expand, with a linear relationship between certain lattice parameters and the molar fraction of promoter, corresponding to Vegard's law [181]. For example, $\mathrm{Mn}$ or Fe cause a contraction [113]. In light of the formation of solid solutions it can be understood as to why there exists a correlation between the pentane conversion and the ionic radius of the promoter [112]. The valence of the promoter ions differs from that of zirconium and charges have to be compensated in the lattice, e.g. by creating oxygen vacancies to balance incorporation of ions with a valence < + IV. Hence, the promoters alter the geometric and electronic structure of the zirconia matrix.
Promotion sometimes results in a slight increase of surface area [24,134], but not always [144]. The differences in surface area seem more pronounced when the calcination produces an unpromoted sulfated zirconia with significant amounts of monoclinic phase while the promoters stabilize the tetragonal phase with its typically higher surface area (see Fig. 4). A 0-67\% higher sulfate content is observed in promoted in comparison to unpromoted sulfated zirconia samples $[24,127,134]$. The promoters affect the reducibility of the oxo-anions on zirconia. In the presence of $\mathrm{Mn}, \mathrm{Fe}$ or $\mathrm{Ga}$, the reduction temperature of sulfate is decreased $[134,182,183]$ and in presence of $\mathrm{Ga}$, tungstate is more easily reducible [184].

While the choice of promoter type and content is straightforward, it is unclear whether the synthesis should target the dissolution of the promoter ions in the zirconia lattice or the formation of surface species. Evidence exists for both scenarios, i.e. either incorporated or the surface promoter species may be catalytically relevant, as discussed in Ref. [113].

\subsection{Addition of Promoters}

Promoters can be introduced at the solution stage before formation of the primary solid, they can be impregnated onto the primary solid, or they can be added to the crystalline oxide, always followed by calcination. It would seem that the first method should produce preferably incorporated species while the last method should produce preferably surface species. The literature though is not in agreement as to which method produces predominantly which species [113]. Fig. 5 shows a more pronounced effect of the promoters on the lattice constant for preparation via coprecipitation in comparison to incipient wetness impregnation, suggesting that indeed incorporation is furthered when zirconium and promoter ion species are well interspersed in the primary solid.

Coprecipitation from a mixed solution of zirconium and promoter ions has been applied to introduce e.g. Al, $\mathrm{Ga}, \mathrm{Ti}, \mathrm{Cr}, \mathrm{Mn}, \mathrm{Fe}, \mathrm{Co}$, or Ni $[24,117,127,134]$; the sulfate can be added afterwards [127]. If the promoters are applied by impregnating a solid and the oxo-anion is already present, the solubility of the oxo-anion in the impregnation solution will have to be considered. Even after calcination, the sulfate in sulfated zirconia is water soluble and will be partially removed in aqueous medium $[113,185]$ A frequently applied method is the incipient wetness technique $[14,15]$, which suppresses the solubility problem. The order of adding sulfate and promoters to the primary solid via incipient wetness impregnation does not result in significant differences in $n$-butane isomerization activity [186]. If Al- or Ga-promoted sulfated zirconia are prepared by first introducing the promoters and then the sulfate, coprecipitation yields superior catalysts in comparison to wet impregnation [24].

Calcination of physical mixtures of sulfated zirconia with $\mathrm{FeSO}_{4}$, sulfated $\mathrm{Fe}_{2} \mathrm{O}_{3}$ or $\mathrm{Fe}_{2} \mathrm{O}_{3}$ at $723-873 \mathrm{~K}$ also 


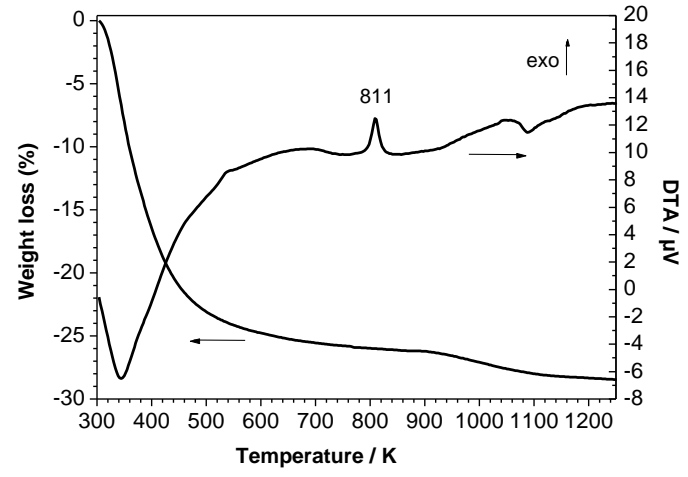

Figure 6: Thermogravimetry and differential thermal analysis data for sulfated hydrous zirconia (MEL XZO 682). Heating rate $7 \mathrm{~K}$ $\min ^{-1}$.

results in catalysts with promoted activity in $n$-butane isomerization [187].

\subsubsection{Calcination}

\subsection{Events during Calcination}

During calcination, a largely disordered hydroxidetype precursor is converted into a crystalline metal oxide. The chemical reactions that occur are dehydration and condensation reactions such as dehydroxylation, which leads to the formation of oxo-bridges (oxolation) between the metal cations [188]. Further components that are able to cleave out volatile compounds may be decomposed, i.e. $\mathrm{NH}_{3}$ may be released from ammonium, $\mathrm{NO}_{\mathrm{x}}$ from nitrates, $\mathrm{SO}_{2}$ and $\mathrm{O}_{2}$ from sulfate. Also from other oxo-anions volatile species can be produced, e.g. $\mathrm{MoO}_{3}$. Redox processes can occur through reaction with the oxygen of the calcination atmosphere or through re-reaction with volatilized species, affecting the valences of the catalyst components. Surfactant molecules would be combusted. Structure and morphology change considerably during calcination. The oxide crystallizes and particles coalescence, leading to a loss in surface area and a change in the porosity.

In Fig. 6. , thermogravimetry and differential thermal analysis data are presented for an ammonium sulfate treated hydrous zirconia (for further data of zirconia-based materials see Refs. [91,136,189,190,191]). The TG curve is characterized by a large weight loss of more than $25 \%$ that extends to $873 \mathrm{~K}$, and a second, smaller weight loss that sets in at about $900 \mathrm{~K}$. The first loss is connected to the evaporation of water and decomposition of ammonium, the second to the decomposition of sulfate. The DTA curve shows the water loss and the sulfate decomposition to be endothermic, and additionally shows an exothermic peak at about $800 \mathrm{~K}$. The origin of this "glow exotherm" has been debated. As heat-generating processes crystallization

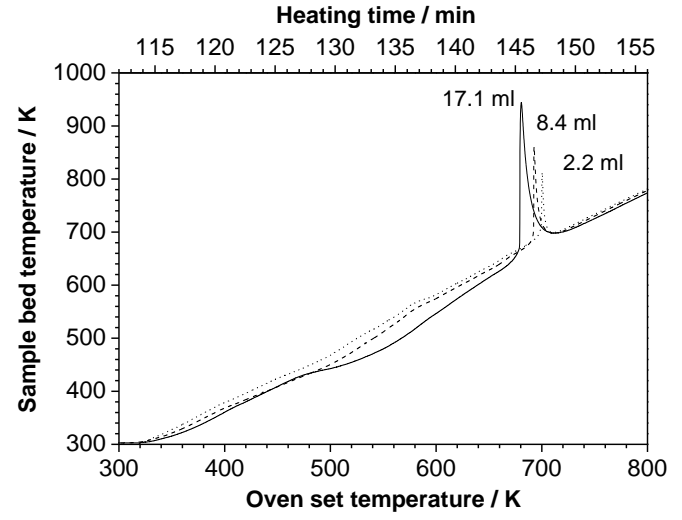

Figure 7: Actual sample temperature of hydrous zirconia (center of bed) as a function of oven set temperature with precursor volume as a parameter. Heating rate $3 \mathrm{~K} \mathrm{~min}^{-1}, 200 \mathrm{ml} \mathrm{min}^{-1}$ synthetic air flow. Samples placed in quartz boats of different volumes [204].

[192,193], loss of internal surface hydroxyl groups [194], and coalescence of small particles to larger ones [195,196] have been proposed.

The enthalpies derived from thermal analysis for, presumably, the crystallization of tetragonal or monoclinic zirconia show a wide spread from -4.3 to $-58.6 \mathrm{~kJ} \mathrm{~mol}^{-1}$ [91,191,192,193,197-201]. The energetic difference between the two phases is small, the monoclinic is about $5 \mathrm{~kJ}$ $\mathrm{mol}^{-1}$ more stable $[199,202]$. The discrepancies in enthalpies can be ascribed to variations in the initial and final states. The properties of "hydrous zirconia" strongly depend on the procedure of preparation, and this state is usually not closely investigated. The final state is also insufficiently characterized in that only the detected phases are considered but not amorphous fractions or properties such as crystallite sizes and surface areas.

From the thermal analysis data it is obvious that during calcination considerable mass and heat transfer occurs, which, particularly when working on preparative scale, may be limited. The chemistry will be influenced by the mass transfer conditions, because of gas exchange with the surrounding atmosphere, e.g. the condensation chemistry will be affected by the water vapor partial pressure. Also surface diffusion and hence zirconia crystallite growth is reportedly accelerated by water vapor [203]. Any volatile species could be re-deposited on the surface.

\subsection{Effect of Bed Volume and Packing}

In Fig. 7, the actual sample temperature of hydrous zirconia during the heat-up phase of the calcination program is displayed. There are significant deviations from the planned ramp, which differ depending on the sample volume employed [204,205]. The sample temperature lags behind the oven set temperature, and more so with 


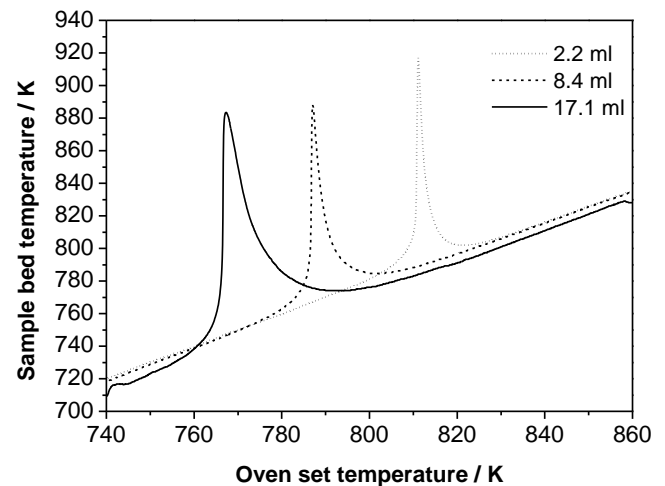

Figure 8: Actual sample temperature of hydrous zirconia promoted with $0.5 \mathrm{wt} \% \mathrm{Mn}$ (center of bed) as a function of oven set temperature with precursor volume as a parameter. Heating rate 3 $\mathrm{K} \mathrm{min}^{-1}, 200 \mathrm{ml} \mathrm{min}^{-1}$ synthetic air flow, $3 \mathrm{~h}$ holding time at $923 \mathrm{~K}$. Samples placed in quartz boats of different volumes [204].

increasing sample volume, because of the endothermic evaporation of water. Retention of water vapor in a tightly packed bed will delay condensation reactions, which should lead to higher surface areas. At oven temperatures of 675 to $700 \mathrm{~K}$, the bed temperature exhibits a brief, but significant overshoot. The overshoot amounts to $260 \mathrm{~K}$ for a $17.1 \mathrm{ml}$ volume, with an increase of $45 \mathrm{~K} \cdot \mathrm{s}^{-1}$. The curves indicate explosion kinetics; heat cannot be dissipated as fast as it is produced. The onset shifts to lower temperature with increasing volume, probably due to restricted heat transfer with the small surface-to-volume ratio and more complete enclosure of the bed in the larger quartz boats.

This violent reaction is designated in the literature as "glow phenomenon", relating to emission of visible light, and was first reported by Berzelius in 1812 [206,207]. For zirconia, it was first mentioned in 1818 [208] and soon more thoroughly investigated $[209,210]$. The phenomenon is also observed during the formation of chromium oxide, iron oxide and titania and is thus of general relevance; however, it does not occur during alumina formation $[195,210]$. Additives of any kind shift the glow event to higher temperature $[189,190,196,917,204,205]$ and subdue or suppress it $[193,195]$, for sulfate the exotherm temperature shifts linearly with content [190]. Estimation of the expected temperature overshoot from the enthalpy changes due to crystallization or surface area loss, under the assumption of quasi-adiabatic conditions, shows that both processes can individually account for the phenomenon [205].

In Fig. 8, the actual temperature curves during calcination are shown for a sulfated hydrous zirconia material promoted with $0.5 \mathrm{wt} \% \mathrm{Mn}$. The addition of sulfate and $\mathrm{Mn}$ shifts the onset of the overheating to about $100 \mathrm{~K}$ higher temperature. Fig. 9 shows the nitrogen adsorption and desorption isotherms for the obtained materials. The hysteresis loop becomes more pronounced with increasing bed volume. The surface area increases slightly from 92 to 96 to $106 \mathrm{~m}^{2} \mathrm{~g}^{-1}$, consistent with the idea of inhibition of

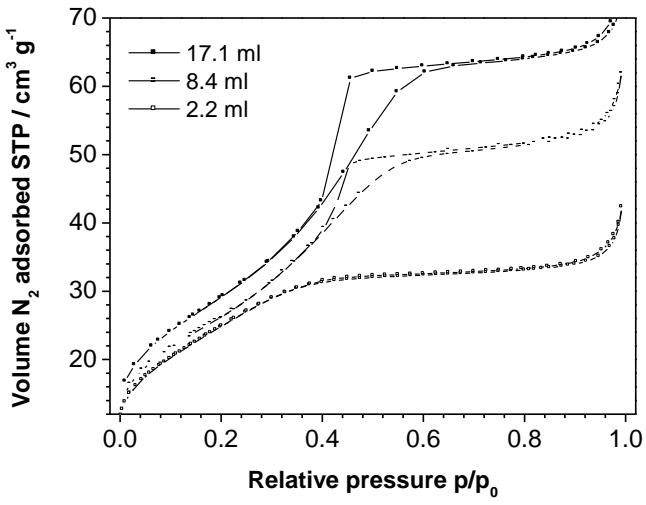

Figure 9. Adsorption and desorption branches of nitrogen adsorption isotherms at $77 \mathrm{~K}$. Sulfated zirconia promoted with $0.5 \mathrm{wt} \%$ Mn.

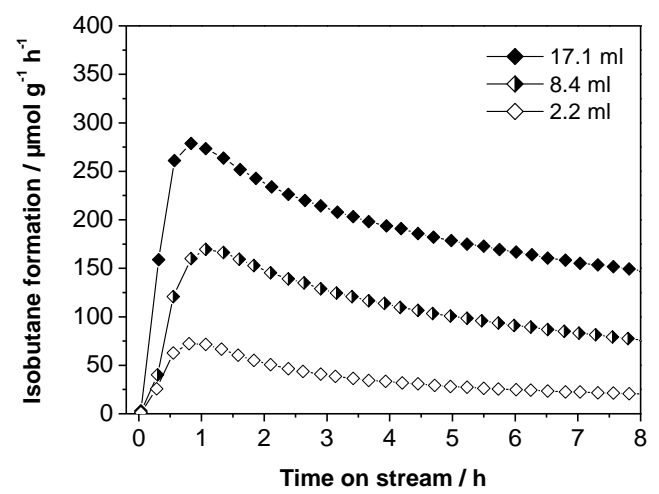

Figure 10: Isobutane formation rate vs. time on stream for sulfated zirconia promoted with $0.5 \mathrm{wt} \% \mathrm{Mn}$. Activation: $0.5 \mathrm{~h}$ at $723 \mathrm{~K}$ in $\mathrm{N}_{2}$. Reaction conditions: $500 \mathrm{mg}$ catalyst, $1 \mathrm{kPa} n$-butane in $\mathrm{N}_{2}$ at atmospheric pressure, $338 \mathrm{~K}, 80 \mathrm{ml} \mathrm{min}^{-1}$ total flow.

oxolation and coalescence by water retained in a larger bed. In Fig.10, the catalytic activity data are presented for the same set of samples. The rates increase significantly with the volume used for the calcination, excluding surface area as a single explanation for the differences.

The data show that variations in the bed size and packing during calcination can produce different materials from a single precursor batch [204,205]. Although the nominal conditions (heating ramp, holding temperature and time, atmosphere) are identical in these calcinations, the samples experience quite different actual conditions. During the initial phase, the water vapor partial pressure will affect the condensation chemistry. Crystallization starts before overheating is observed. Surface area and diffractograms of a sample that was cooled down directly after the glow largely correspond to those of samples that underwent the complete heating program, indicating that structure and morphology are determined during the overheating [205]. During the temperature overshoot, the desired maximum 


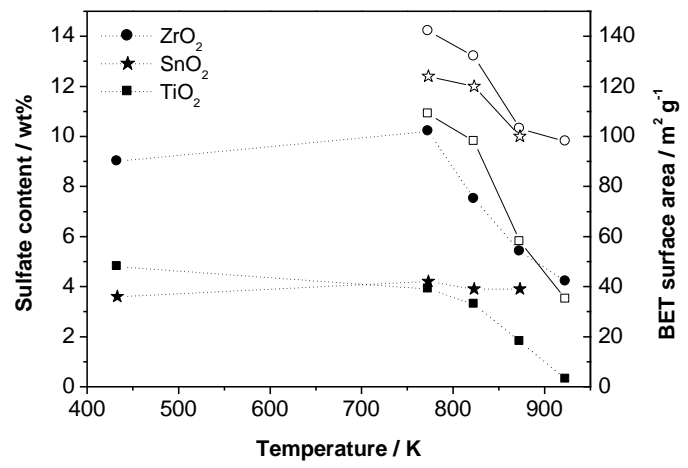

Figure 11: Sulfate content (solid symbols) and BET surface area (open symbols) as a function of calcination temperature after drying at $433 \mathrm{~K}$ with oxide type as a parameter (after Ref. [124]).

temperature may be exceeded, which allows for a chemistry that is not possible within the planned program. Enhanced ion mobility within the forming solid but also volatilization and re-anchoring with restructuring of surface species can be envisioned. Through the fairly rapid cooldown after the overshoot non-equilibrium states might be quenched. The subsequent holding time at high temperature does not equalize differences evoked during the heat-up phase. Consistently, it has been attempted to relate high $n$ pentane isomerization activity to a sharp and high exothermal peak [191]. In part, the reported lack of reproducibility [211] of this catalyst may originate from underestimating the importance of such parameters. Samples calcined in different setups are not comparable on an absolute scale, and the data discussed in the following thus illustrate trends.

\subsection{Effect of Calcination Temperature on Physical Properties}

The calcination temperature has a major influence on the phase composition, the surface area and the sulfate content. Upon heating, the metastable tetragonal (cubic) phase is formed first. The higher the calcination temperature, the more likely the formation of monoclinic zirconia. Crystalline zirconia appears at about $663 \mathrm{~K}$ in non-sulfated samples [212]. The crystallite size of the tetragonal phase and the fraction of the monoclinic phase increase with increasing calcination temperature $[89,212]$. In the presence of sulfate, the tetragonal phase is stabilized and even at temperatures of $933 \mathrm{~K}$, purely tetragonal material can be obtained [212]. However, typically, formation of monoclinic phase sets in at calcination temperatures above ca. $873 \mathrm{~K}$ [37]. The crystallite size of the metal oxide in sulfated zirconia, titania and tin oxide prepared via sulfate decomposition was found to be constant up to the calcination temperature that gives the largest surface area [31].

The surface area of pure zirconia decreases with increasing calcination temperature above $773 \mathrm{~K}$, with a

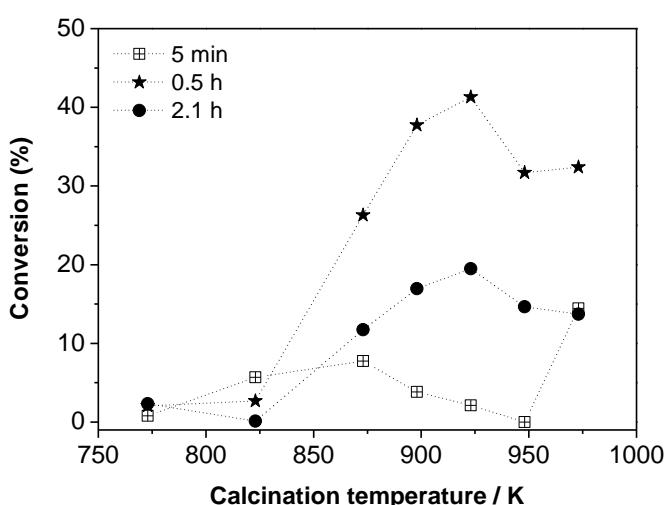

Figure 12: Conversion at different times on stream for sulfated zirconia promoted with $1.5 \mathrm{wt} \% \mathrm{Fe}$ and $0.5 \mathrm{wt} \% \mathrm{Mn}$. Calcination: $5 \mathrm{~g}$ raw material supported on frit in vertical open tube, $3 \mathrm{~h}$ heating phase to desired temperature, $4 \mathrm{~h}$ holding time, free air convection. Activation: $1.5 \mathrm{~h}$ at $723 \mathrm{~K}$ in $\mathrm{N}_{2}$. Reaction conditions: $1.5 \mathrm{~g}$ catalyst, $0.5 \mathrm{kPa} n$-butane in $\mathrm{N}_{2}$ at atmospheric pressure, $373 \mathrm{~K}, 80 \mathrm{ml}$ $\min ^{-1}$ total flow.

smaller effect for materials with a low starting surface area [95,101]. The surface area drops significantly once the temperature exceeds that of the glow exotherm [213]. The decrease is also observed for oxo-anion modified zirconia, e.g. for sulfated zirconia from $135 \mathrm{~m}^{2} \mathrm{~g}^{-1}$ at $773 \mathrm{~K}$ to $40 \mathrm{~m}^{2}$ $\mathrm{g}^{-1}$ at $1173 \mathrm{~K}$ [53] and for tungstated zirconia from $100 \mathrm{~m}^{2}$ $\mathrm{g}^{-1}$ at $973 \mathrm{~K}$ to $35 \mathrm{~m}^{2} \mathrm{~g}^{-1}$ at $1223 \mathrm{~K}$ [99]. A linear correlation of surface area and temperature is seen between 773 and $1223 \mathrm{~K}$ [188]. The trends for different metal oxides are shown in Fig. 11. The sulfate content is also reduced by calcination, and this occurs in parallel with a loss of surface area as Fig.11 demonstrates. Literature data vary as to the temperature where the losses start; values also depend on the initial sulfur content and range from $473 \mathrm{~K}$ to $873 \mathrm{~K}$ $[36,37,101,212,214]$. It has been inferred that sulfate in certain crystallographic locations desorbs preferably and highly uncoordinated $\mathrm{Zr}^{4+}$ sites, which are strong Lewis acid sites, are generated at calcination above $773 \mathrm{~K}$ [215]. With increasing calcination temperature, the number of $\mathrm{OH}$ groups on the surface decreases [183].

\subsection{Effect of Calcination Temperature on Cat- alytic Performance}

The best performance in $n$-butane isomerization is exhibited by sulfated zirconia that has been calcined at 823-873 K [187], 873 K [53], 893 K [216], or 875-900 K [214]. A minimum temperature of $773 \mathrm{~K}$ is required to obtain an active material [215]. Much higher temperatures are necessary for tungstated zirconia, about $1100-1200 \mathrm{~K}$ [99].

The initial activity of the obtained sulfated metal oxide catalyst in cumene cracking depended on the calcination temperature employed in decomposing the commercial 
$\mathrm{Zr}\left(\mathrm{SO}_{4}\right)_{2}$ or $\mathrm{Ti}\left(\mathrm{SO}_{4}\right)_{2}$ precursor. The activity increased with increasing calcination temperature, reaching a maximum at $900 \mathrm{~K}$ for the titania and at $1000 \mathrm{~K}$ for the zirconia catalyst [114]. The increase in activity was found to be parallel to an increase in surface area [31].

The optimal temperature in the presence of promoters has been evaluated for sulfated zirconia promoted with $\mathrm{Fe}$ and $\mathrm{Mn}$. The results are shown in Fig. 12 [217]. Because the activity of these catalysts changes rapidly, several data points representing different times on stream have been selected. The best performance is obtained after calcination at $923 \mathrm{~K}[166,217]$.

\subsection{Effect of Holding Time}

Little is known about the effect of holding time. Zirconia crystallization and crystallite growth do not progress further after $2 \mathrm{~h}$ at $\geq 773 \mathrm{~K}$ [218]. If the temperature is high enough to decompose sulfate, e.g. $873 \mathrm{~K}$, then the sulfate content will decrease with time [219]. Time and temperature can be used complementary, e.g. calcination for $12 \mathrm{~h}$ at $823 \mathrm{~K}$ delivers a promoted sulfated zirconia catalyst yielding equal conversion in alkane isomerization as one calcined for $4 \mathrm{~h} 848 \mathrm{~K}$ [13].

\subsection{Summary Calcination}

The calcination is a critical step, but it is difficult to name optimal conditions for two reasons. First, phase composition, surface area, and oxo-anion content are interdependent properties. During calcination, excess sulfate or tungstate, i.e. more than can be accommodated in a chemisorbed monolayer, will be converted to oxides, and more so as the surface area shrinks with increasing temperature. In the case of sulfate, oxide formation means volatilization, in the case of tungstate, the excess remains in the sample in the form of $\mathrm{WO}_{3}$ [99]. The sulfate content thus will be diminished, typical sulfur losses during calcination $(2 \mathrm{~h} 873$ $\mathrm{K}$ ) depend on the sulfur loading and amount to $20-50 \%$ of the initial content [56]. Concurrent with sulfate loss and surface area shrinkage, monoclinization of zirconia may occur.

Second, the number of parameters influencing the outcome of the calcination is high. Because of the condensation chemistry when starting from a hydrous oxide precursor and the strongly exothermic crystallographic and morphological changes, heat and mass transfer conditions are extremely important. Restriction of heat transfer and gas exchange seems favorable, contrary to IUPAC recommendations to use moving beds [58]. Most important is to realize that stating maximum temperature and holding time is insufficient; bed size and packing, gas exchange conditions and heating rates must be specified and controlled to render calcinations reproducible.

\subsubsection{Sulfation of Thermally Treated, Crys- talline Oxides}

It has been claimed several times that adding sulfate to crystalline $\mathrm{ZrO}_{2}$ does not yield an active catalyst [37], or yields only about one order of magnitude less active catalysts [214]. Specifically, the activity of the resulting materials drops when the hydroxide is pretreated at a temperature that will induce crystallization [2]. The situation is different for other oxides, e.g. materials active in acid catalysis can be generated from $\mathrm{Fe}_{2} \mathrm{O}_{3}$ [220,221].

\subsection{Sulfation with Aqueous Solutions (Solid - Liquid Phase)}

Impregnation of zirconia and calcination at $873 \mathrm{~K}$ produces a material active in $n$-butane isomerization, with the activity related to the surface area [29]. Incipient wetness impregnation with ammonium sulfate and calcination at a temperature of at least $773 \mathrm{~K}$ also results in a sample active in $n$-butane isomerization [96].

\subsection{Sulfation via Gas Phase (Solid - Gas Phase)}

$\mathrm{SO}_{3}$ treatment at $573 \mathrm{~K}$ has been used to sulfate $\mathrm{Fe}_{2} \mathrm{O}_{3}$, with positive results in cyclopropane isomerization; also $\mathrm{H}_{2} \mathrm{~S}$ and $\mathrm{SO}_{2}$ treated $\mathrm{Fe}_{2} \mathrm{O}_{3}$ samples became active after oxidation at 723-773 K [221]. Equally, exposure of $\mathrm{ZrO}_{2}$ to $\mathrm{H}_{2} \mathrm{~S}$ or $\mathrm{SO}_{2}$ followed by treatment in an excess of $\mathrm{O}_{2}$ at $723 \mathrm{~K}$ yields virtually identical IR spectra [119]. Moreover, the spectra correspond to those obtained after aqueous solution impregnations using $\mathrm{H}_{2} \mathrm{SO}_{4},\left(\mathrm{NH}_{4}\right)_{2} \mathrm{SO}_{4}$, or $\mathrm{Zr}\left(\mathrm{SO}_{4}\right)_{2}$ and suitable activation. At low coverage, monosulfate species are observed, while at more than 250 $\mu \mathrm{mol} \mathrm{S} \mathrm{g}{ }^{-1}$ an $\mathrm{S}_{2} \mathrm{O}_{7}$ type species appears, indicating that a high sulfate density can be achieved via gas phase reaction. It is possible to generate an active material via gas phase sulfation of predominantly monoclinic zirconia using $\mathrm{H}_{2} \mathrm{SO}_{4}$ vapor [214].

$\mathrm{SO}_{3}$ can also be employed as sulfating agent. Exposure of zirconia supported on silica at $673 \mathrm{~K}$ generates a catalyst active in transalkylation of benzene and diethylbenzene, though only after hydrating the material [222]. The sulfur content of sulfated zirconia can be increased by treatment with $\mathrm{SO}_{3}$ at $673 \mathrm{~K}$; an increase from 0.44 to 0.64 mmol g ${ }^{-1}$ or $6 \mathrm{wt} \%$ was reported [24]. In a series of samples, the total amount of sulfate after $\mathrm{SO}_{3}$ treatment was found to be proportional to the fraction of monoclinic material in the sample, with loadings reaching $1.15 \mathrm{mmol} \mathrm{g}^{-1}$ or $12 \mathrm{wt} \% . \mathrm{SO}_{3}$ treatment enhances the butane isomerization activity of sulfated zirconia, and zirconia becomes active. A sample prepared via $\mathrm{SO}_{3}$ sulfation, containing only $30 \%$ 
tetragonal zirconia, was even found to be catalytically more active than a sample created by calcination of amorphous zirconium hydroxide. Previous work confirms that monoclinic zirconia can be sulfated to give an active catalyst, yet only at high sulfate loading and at the expense of low sulfate stability and rapid deactivation [223].

Calcination of pure zirconia leads to a lower surface area and a monoclinic fraction is more easily formed. Successful sulfation of crystalline materials requires a high temperature; hence it appears that a reaction of the sulfur species with the support must be initiated.

\subsection{Sulfation of Zirconia Using Solid Sulfate Precursors}

Kneading calcined zirconia (773 K) with ammonium sulfate followed by a second calcination at $773 \mathrm{~K}$ produces a material active for butene double bond isomerization and benzoylation of anisole [126].

\subsubsection{Addition of Noble Metals}

Noble metals can be added at different stages of the preparation, e.g. during alkoxide hydrolysis [224], before calcination [225,226], or after a calcination step [227]. Normal impregnation methods are employed; non-water soluble noble metal salts can be kneaded together with the primary solid [225]. Noble metals are also effective when not located directly on the oxo-anion modified oxide [187].

\subsubsection{Activation}

Reports on the optimal activation temperature vary significantly. For sulfated zirconia, 523-573 K [216], 573 [228], $590 \mathrm{~K}$ [229], $673 \mathrm{~K}$ [94,228], $723 \mathrm{~K}$ [55], or $923 \mathrm{~K}$ [214] have been reported as optimal for high $n$-butane isomerization activity. The individual materials may favor different activation temperatures; however, also atmosphere, heating rates and holding times may play a role.

The performance of promoted sulfated zirconia catalysts, e.g. with $\mathrm{Fe}$ and $\mathrm{Mn}$ as promoters, appears to be less sensitive to the temperature, particularly if the sample is activated in air and not in inert gas [152]. Temperatures of 623-723 $\mathrm{K}$ have been reported to generate the highest maximum activity $[152,166]$

Noble-metal containing sulfated zirconia catalysts require a reduction step, with the inherent danger of reducing and volatilizing the sulfate. In the presence of $\mathrm{Pt}$, the sulfate reduction temperature is shifted by about $-200 \mathrm{~K}$ into the range $733-773 \mathrm{~K}$ [230]. The butane isomerization activity of Pt-doped sulfated zirconia decreases to zero with increasing reduction temperature in the range 583 to $693 \mathrm{~K}$ [46]. The situation will be more complicated if promoters are present, e.g. Mn-promoted sulfated zirconia becomes inactive after treatment in $50 \% \mathrm{H}_{2}$ at $703 \mathrm{~K}$ [231].

Similar to sulfate, tungstate is much more easily reduced in the presence of $\mathrm{Pt}$; $\mathrm{W}^{5+}$ species are formed at room temperature, but the systems are active [232]. Pt in Pt-doped Fe-promoted tungstated zirconia is reduced to metal at room temperature, and hence under hydroisomerization conditions is also expected to be metallic, rendering an extra reduction step unnecessary [16].

\subsubsection{Summary}

The catalysts discussed here contain four types of components, namely matrix oxide, oxo-anion, promoter, and noble metal. If the oxide and oxo-anions precursors are associated in solution, then the metal cation's tendency for hydrolysis and for complexation with the oxo-anion will determine the nature of the primary solid. Alternatively, oxo-anions can be introduced to a solid hydrous or crystalline oxide.

If promoters are added, then the solid state chemistry of the matrix oxide and its ability to accommodate foreign cations in its lattice come into play; on the other hand, oxoions will compete to form stable compounds with the promoter ions, e.g. $\mathrm{Al}_{2}\left(\mathrm{SO}_{4}\right)_{3}$. In the first case, the geometric and the electronic structures of the matrix oxide can, though not independently, be tuned. Zirconia thus makes an interesting matrix oxide for oxo-anion modification, because through varying its properties by promoter incorporation, the reactivity, e.g. the reducibility, of the oxo-anion can be determined.

All preparations require a high temperature thermal treatment after bringing the precursors together. The calcination conditions are difficult to control because the reactions occurring in the sample consume and produce significant amounts of heat and gases; heat and mass transfer conditions thus have to be carefully considered. The thermal treatment is thus a key step in the formation of oxo-anion modified oxide catalysts. As a consequence of the close interaction of the individual catalyst components, properties like phase composition, surface area and oxoanion content are interdependent, and determine further properties, e.g. the acid site distribution. A targeted synthesis of oxo-anion modified oxides with specific properties is thus a challenge. 


\section{References}

[1] V.C.F. Holm, G.C. Bailey, US Patent 3, 032, 599, assigned to Philips Petroleum Co., 1962.

[2] M. Hino, S. Kobayashi, K. Arata, J. Am. Chem. Soc. 1979, 101, 6439.

[3] M. Hino, K. Arata, J. Chem. Soc., Chem. Commun. 1980 851.

[4] F. Schmidt, Appl. Catal. A: General 2001, 221, 15, and references therein.

[5] N. Lohitharn, J.G. Goodwin Jr., J. Catal. 2007, 245, 198

[6] G.D. Yadav, J.J. Nair, Micropor. Mesopor. Mater. 1999, 33,1 , and references therein

[7] X. Song, Y. Sayari, Catal. Rev. Sci. Eng. 1996, 38, 329, and references therein.

[8] K. Arata, M. Hino, Mater. Chem. Phys. 1990, 26, 213, and references therein

[9] C.D. Chang, F.T. DiGuiseppi, J.G. Santiesteban, US patent 5, 780, 382, assigned to Mobil Oil Corporation, 1998.

[10] K. Arata, Appl. Catal. A: General 1996, 146, 3, and references therein.

[11] C.D. Chang, S. Han, R.A. Morrison, J.G. Santiesteban, US patent 5, 999, 643, assigned to Mobil Oil Corporation, 1999.

[12] P.T. Patil, K.M. Malshe, P. Kumar, M.K. Dongare, E Kemnitz, Catal. Comm. 2002, 3, 411

[13] E.J. Hollstein, J.T. Wei, C.Y. Hsu, US Patent 4, 918, 041, assigned to Sun Refining and Marketing Co., 1990.

[14] C.-Y. Hsu, C.R. Heimbuch, C.T. Armes, B.C. Gates, J. Chem. Soc., Chem. Commun. 1992, 1645.

[15] F.C. Lange, T.-K. Cheung, B.C. Gates, Catal. Lett. 1996 41,95 .

[16] S. Kuba, B.C. Gates, R.K. Grasselli, H. Knözinger, Chem. Commun. 2001, 321

[17] R. Ahmad, J. Melsheimer, F.C. Jentoft, R. Schlögl, J. Catal. 2003, 218, 365 .

[18] S. Kuba, P. Lukinskas, R. Ahmad, F.C. Jentoft, R.K. Grasselli, B.C. Gates, H. Knözinger, J. Catal. 2003, 219, 376

[19] H. Liu, G.D. Lei, V. Adeeva, W.M.H. Sachtler, J. Molec Catal. 1995, 100, 35.

[20] S. Kuba, P. Lukinskas, R.K. Grasselli, B.C. Gates, H Knözinger, J. Catal. 2003, 216, 353.

[21] J. Luo, R. Stevens, J. Am. Ceram. Soc. 1999, 82, 1922.

[22] C. Morterra, G. Cerrato, F. Pinna, M. Signoretto, J. Catal. 1995, 157, 109.

[23] W. Stichert, F. Schüth, S. Kuba, H. Knözinger, J. Catal. 2001, 198, 277.

[24] J.A. Moreno, G. Poncelet, J. Catal. 2001, 203, 453.

[25] X. Li, K. Nagaoka, R. Olindo, J.A. Lercher, J. Catal. 2006, $238,39$.

[26] X. Li, K. Nagaoka, L.J. Simon, J.A. Lercher, S. Wrabetz, F.C. Jentoft, C. Breitkopf, S. Matysik, H. Papp, J. Catal. 2005, 230, 214.

[27] M.A. Risch, E.E. Wolf, Appl. Catal. A: General 1998, 172, L1.

[28] C. Breitkopf, A. Garsuch, H. Papp, Appl. Catal. A: General 2005, 296, 148.

[29] T. Riemer, D. Spielbauer, M. Hunger, G.A.H. Mekhemer, H. Knözinger, J. Chem. Soc., Chem. Commun. 1994, 1181.

[30] M.G. Cutrufello, U. Diebold, R.D. Gonzalez, Catal. Lett $\mathbf{2 0 0 5}, 101,5$.

[31] D. Fraenkel, Ind. Eng. Chem. Res. 1997, 36, 52.

[32] S. Melada, M. Signoretto, F. Somma, F. Pinna, G. Cerrato, G. Meligrana, C. Morterra, Catal. Lett. 2004, 94, 193.
[33] M. K. Mishra, B. Tyagi, R.V. Jasra, Ind. Eng. Chem. Res. 2003, 42, 5727.

[34] D. Fărcaşiu, J.Q. Li, S. Cameron, Appl. Catal. A: General 1997, 154, 173

[35] J.C. Yori, J.M. Parera, Appl. Catal. A: General 1995, 129 , L151.

[36] P. Nascimento, C. Akratapoulou, M. Oszagyan, G. Coudurier, C. Travers, J.F. Joly, J.C. Vedrine, Proceedings of the $10^{\text {th }}$ International Congress on Catalysis, July 19-24, 1992, Budapest, Hungary, New Frontiers in Catalysis, L. Guczi, F. Solymosi, P. Tetényi (Eds.), Elsevier, Amsterdam, 1993, p. 1185.

[37] F.R. Chen, G. Coudurier, J.-F. Joly, J.C. Védrine, J. Catal. 1993, 143, 616 .

[38] A. Hofmann, J. Sauer, J. Phys. Chem. B, 2004, 108, 14652

[39] B.S. Klose, F.C. Jentoft, R. Schlögl. J. Catal. 2005, 233, 68

[40] B.S. Klose, Dissertation, Technische Universität Berlin, 2005, http://opus.kobv.de/tuberlin/volltexte/2005/1177/.

[41] X. Li, K. Nagaoka, L.J. Simon, R. Olindo, J.A. Lercher, A. Hofmann, J. Sauer, J. Am. Chem. Soc. 2005, 127, 16159.

[42] C. Breitkopf, H. Papp, X. Li, R. Olindo, J.A. Lercher, R. Lloyd, S. Wrabetz, F.C. Jentoft, K. Meinel, S. Förster, K.M. Schindler, H. Neddermeyer, W. Widdra, A. Hofmann, J. Sauer, Phys. Chem. Chem. Phys., submitted.

[43] F. Babou, G. Coudurier, J.C. Vedrine, J. Catal. 1995, 152, 341.

[44] K. Biró, F. Figueras,S. Békássy, Appl. Catal. A: General 2002, 229, 235

[45] J.R. Sohn, S.H. Lee, Appl. Catal. A: General 2004, 266, 89.

[46] K. Ebitani, J. Konishi, H. Hattori, J. Catal. 1991, 130, 257.

[47] F.-S. Xiao, Topics in Catal. 2005, 35, 9, and references therein.

[48] V.M. Benítez, C.R. Vera, C.L. Pieck, F.G. Lacamoire, J.C. Yori, J.M. Grau, J.M. Parera, Catal. Today 2005, 107-108, 651.

[49] R. Akkari, A. Ghorbel, N. Essayem, F. Figueras, J. Sol-Gel Sci. Tech. 2005, 33, 121.

[50] R. Akkari, A. Ghorbel, N. Essayem, F. Figueras, J. Sol-Gel Sci. Tech. 2006, 38, 185 .

[51] X. Yang, R.E. Jentoft, F.C. Jentoft, Catal. Lett. 2006, 106, 195.

[52] M.A. Ecormier, K. Wilson, A.F. Lee, J. Catal. 2003, 215, 57.

[53] D.A. Ward, E.I. Ko, J. Catal. 1994, 150, 18

[54] B.-Y. Zhao, X.-P. Xu, H.-R. Ma, D.-H. Sun, J.-M. Gao, Catal. Lett. 1997, 45, 237.

[55] H.K. Mishra, K.M. Parida, Appl. Catal. A: General 2002, $224,179$.

[56] A.F. Bedilo, K.J. Klabunde, J. Catal. 1998, 176, 448

[57] D.J. Zalewski, S. Alerasool, P.K. Doolin, Catal. Today 1999, 53,419

[58] J. Haber, J.H. Block, B. Delmon, Pure \& Appl. Chem. 1995 $67,1257$.

[59] A.L. Hock, Chemistry and Industry 1974, 2, 864.

[60] C.E. Morris, T.L. Vigo, C.M. Welch, Textile Res. J. 1981, 90.

[61] W.B. Blumenthal, Ind. Eng. Chem. 1954, 46, 528

[62] A. Clearfield, P.A. Vaughan, Acta Cryst. 1956, 9, 555.

[63] G.M. Muha, P.A. Vaughan, J. Chem. Phys. 1960, 33, 194.

[64] S. Hannane, F. Bertin, J. Bouix, Bull. Soc. Chim. Fr. 1990, 127,43 .

[65] L.M. Toth, J.S. Lin, L.K. Felker, J. Phys. Chem. 1991, 95 , 3106 . 
[66] M. Åberg, J. Glaser, Inorg. Chim. Acta 1993, 206, 53.

[67] K. Matsui, H. Suzuki, M. Ohgai, J. Am. Ceram. Soc. 1995, $78,146$.

[68] A. Singhal, L.M. Toth, J.S. Lin, K. Affholter, J. Am. Chem. Soc. 1996, 118, 11529.

[69] A. Singhal, L.M. Toth, G. Beaucage, J.-S. Lin, J. Peterson, J. Colloid Interface Sci. 1997, 194, 470.

[70] K. Matsui, M. Ohgai, J. Am. Ceram. Soc. 1997, 80, 1949.

[71] M.Z.-C. Hu, J.T. Zielke, J.-S. Lin, C.H. Byers, J. Mater. Res. 1999, 14, 103.

[72] K. Lee, A. Sathyagal, P.W. Carr, A.V. McCormick, J. Am. Ceram. Soc. 1999, 82, 338.

[73] P. Riello, A. Minesso, A. Craievich, A. Benedetti, J. Phys. Chem. B. 2003, 107, 3390.

[74] R.E. Connick, W.H. McVey, J. Am. Chem. Soc. 1949, 71, 3182.

[75] S. Ahrland, D. Karipides, B. Norén, Acta Chem. Scand. 1963, $17,411$.

[76] A. Clearfield, Rev. Pure Appl. Chem. 1964, 14, 91.

[77] E. Matijevic, Acc. Chem. Res. 1981, 14, 22.

[78] R. Ruer, Z. Anorg. Chem. 1904, 42, 87.

[79] F.G. Baglin, D. Breger, Inorg. Nucl. Chem. Lett. 1976, 12, 173.

[80] U. Ciesla, M. Fröba, G. Stucky, F. Schüth, Chem. Mater. 1999, 11, 227.

[81] M. Falinski, Ann. Chim. 1941, 16, 237.

[82] M. Chatterjee, J. Ray, A. Chatterjee, D. Ganguli, J. Mater. Sci. Lett. 1989, 8, 548.

[83] J. D'Ans, H. Eick, Z. Elektrochem. 1951, 55, 19.

[84] I.J. Bear, W.G. Mumme, Rev. Pure Appl. Chem. 1971, 21, 189.

[85] P.J. Squattrito, P.R. Rudolf, A. Clearfield, Inorg. Chem. 1987, 26, 4240.

[86] O. Hauser, Z. Anorg. Allg. Chem. 1905, 45, 185.

[87] I.G. Atanov, L.M. Zaitsev, Russ. J. Inorg. Chem. 1967, 12, 188.

[88] H. Cölfen, H. Schnablegger, A. Fischer, F.C. Jentoft, G. Weinberg, R. Schlögl, Langmuir 2002, 18, 3500.

[89] G.K. Chuah, S. Jaenicke, S.A. Cheong, K.S. Chan, Appl. Catal. A: General 1996, 145, 267.

[90] R. Sui, A.S. Rizkalla, P.A. Charpentier, Langmuir 2006, 22, 4390.

[91] G.K. Chuah, S. Jaenicke, B.K. Pong, J. Catal. 1998, 175, 80.

[92] G.K. Chuah, S. Jaenicke, T.H. Xu, Surf. Interf. Anal. 1999, 28,131

[93] E. Riedel, Anorganische Chemie, $5^{\text {th }}$ Ed., Walter deGruyter, Berlin, 2002, p. 776.

[94] B. Li, R.D. Gonzalez, Ind. Eng. Chem. Res. 1996, 35, 3141.

[95] G.K. Chuah, S.H. Liu, S. Jaenicke, J. Li, Micropor. Mesopor. Mater. 2000, 39, 381.

[96] D.A. Ward, E.I. Ko, J. Catal. 1995, 157, 321.

[97] D. Tichit, B. Coq, H. Armendariz, F. Figuéras, Catal. Lett. 1996, 38,109 .

[98] V. Pârvulescu, S. Coman, P. Grange, V.I. Pârvulescu, Appl. Catal. A: General 1999, 176, 27.

[99] R.A. Boyse, E.I. Ko, J. Catal. 1997, 171, 191.

[100] H. Althues, S. Kaskel, Langmuir 2002, 18, 7428.

[101] S. Melada, S.A. Ardizzone, C.L. Bianchi, Micropor. Mesopor. Mater. 2004, 73, 203.

[102] S. Melada, M. Signoretto, S.A. Ardizzone, C.L. Bianchi, Catal. Lett. 2001, 75, 199.

[103] C.T. Kresge, M.E. Leonowicz, W.J. Roth, J.C. Vartuli, Nature 1992, 359, 710.

[104] F. Schüth, Chem. Mater. 2001, 13, 3184.
[105] U. Ciesla, S. Schacht, G.D. Stucky, K.K. Unger, F. Schüth, Angew. Chem. 1996, 108, 597; Angew. Chem. Int. Ed. Eng. 1996, $35,541$.

[106] V.N. Romannikov, V.B. Fenelonov, E.A. Paukshtis, A.Yu. Derevyankin, V.I. Zaikovskii, Micropor. Mesopor. Mater. 1998, $21,411$.

[107] D.M. Antonelli, Adv. Mater. 1999, 11, 487.

[108] X. Yang, F.C. Jentoft, R.E. Jentoft, F. Girgsdies, T. Ressler, Catal. Lett. 2002, 81, 25.

[109] Y. Sun, L. Yuan, W. Wang, C.-L. Chen, F.-S. Xiao, Catal. Lett. 2003, 87, 57 .

[110] www.zrchem.com, www.sigma-aldrich.com.

[111] G. Hausinger, A. Reimer, J. Schönlinner, F. Schmidt, German patent application 10033 477, Süd-Chemie AG, 2002.

[112] R.D. Gillespie, M. Cohn, US Patent 6,706,659, assigned to UOP LLC, 2004.

[113] F.C. Jentoft, A. Hahn, J. Kröhnert, G. Lorenz, R.E. Jentoft, T. Ressler, U. Wild, R. Schlögl, C. Häßner, K. Köhler, J. Catal. 2004, 224, 124, and references therein.

[114] K. Arata, M. Hino, N. Yamagata, Bull. Chem. Soc. Jpn. 1990, 63, 244.

[115] E. Escalona Platero, M. Peñarroya Mentruit, C. Otero Areán, A. Zecchina, J. Catal. 1996, 162, 268.

[116] G.D. Yadav, A.D. Murkute, J. Catal. 2004, 224, 218.

[117] Y. Xia, W. Hua, Z. Gao, Appl. Catal. A: General 1999, 185, 293.

[118] R.L. Marcus, R.D. Gonzalez, E.L. Kugler, A. Auroux, Chem. Eng. Comm. 2003, 190, 1601.

[119] M. Bensitel, O. Saur, J.-C. Lavalley, B.A. Morrow, Mater. Chem. Phys. 1988, 19, 147.

[120] J.M. Parera, Catal. Today 1992, 15, 481.

[121] D. Fărcaşiu, J.Q. Li, Appl. Catal. 1995, 128, 97.

[122] C.D. Chang, F.T. DiGuiseppi, J.G. Santiesteban, US patent 5, 780, 382, assigned to Mobil Oil Corporation, 1998.

[123] J.B. Laizet, A.K. Søiland, J. Leglise, J.C. Duchet, Topics in Catal. 2000, 10, 89.

[124] A. Corma, A. Martínez, C. Martínez, Appl. Catal. A: General 1996, 144, 249.

[125] D.F. Stec, R.S. Maxwell, H. Cho, J. Catal. 1998, 176, 14.

[126] V. Quaschning, J. Deutsch, P. Druska, H.-J. Niclas, E. Kemnitz, J. Catal. 1998, 177, 164.

[127] C. Miao, W. Hua, J. Chen, Z. Gao, Catal. Lett. 1996, 37, 187.

[128] Z. Gao, Y. Xia, W. Hua, C. Miao, Topics in Catal. 1998, 6 , 101.

[129] Y.D. Xia, W.M. Hua, Y. Tang, Z. Gao, Chem. Commun. 1999, 1899.

[130] W. Hua, Y. Xia, Y. Yue, Z. Gao, J. Catal. 2000, 196, 104.

[131] P. Canton, R. Olindo, F. Pinna, G. Strukul, P. Riello, M. Meneghetti, G. Cerrato, C. Morterra, A. Benedetti, Chem. Mater. 2001, 13, 1634.

[132] M. Perez-Luna, J.A. Toledo-Antonio, F. HernandezBeltrán, H. Armendariz, A. Garcia Borquez, Catal. Lett. 2002, 83, 201.

[133] M. Hino, K. Arata, React. Kin. Catal. Lett. 2004, 81, 321.

[134] M. Signoretto, S. Melada, F. Pinna, S. Polizzi, G. Cerrato, C. Morterra, Micropor. Mesopor. Mater. 2005, 81, 19.

[135] J.C. Yori, J.M. Parera, Appl. Catal. A: General 1996, 147, 145.

[136] R. Srinivasan, R.A. Keogh, B.H. Davis, Appl. Catal. A: General 1995, 130, 135.

[137] T. Yamamoto, T. Tanaka, S. Takenaka, S. Yoshida, T. Onari, Y. Takahashi, T. Kosaka, S. Hasegawa, M. Kudo, $J$. Phys. Chem. B 1999, 103, 2385. 
[138] R.E. Jentoft, A. Hahn, F.C. Jentoft, T. Ressler, J. Synchrotron Rad. 2001, 8, 563.

[139] M.A. Coelho, D.E. Resasco, E.C. Sikabwe, R.L. White, Catal. Lett. 1995, 32, 253.

[140] E.A. García, E.H. Rueda, A.J. Rouco, Appl. Catal. A: General 2001, 210, 363.

[141] M. Hino, K. Arata, Catal. Lett. 1996, 34, 125.

[142] J.M.M. Millet, M. Signoretto, P. Bonville, Catal. Lett. 2000, 64, 135

[143] J.C. Yori, J.M. Parera, Appl. Catal. A: General 1995, 129, 83.

[144] M. Perez-Luna, J.A. Toledo Antonio, A. Montoya, R. Rosas-Salas, Catal. Lett. 2004, 97, 59.

[145] A. Corma, J.M. Serra, A. Chica, Catal. Today 2003, 81, 495.

[146] M.L. Occelli, D.A. Schiraldi, A. Auroux, R.A. Keogh, B.H. Davis, Appl. Catal. A: General 2001, 209, 165.

[147] C.T. Kresge, C.D. Chang, J.G. Santiesteban, D.S. Shihabi, S.A. Stevenson, J.C. Vartuli, US patent 5, 902, 767, assigned to Mobil Oil Corporation, 1999.

[148] A. Jatia, C. Chang, J.D. MacLeod, T. Okubo, M.E. Davis, Catal. Lett. 1994, 25, 21.

[149] V. Adeeva, G.D. Lei, W.M.H. Sachtler, Appl. Catal. A: General 1994, 118, L11.

[150] A.S. Zarkalis, C.-Y. Hsu, B.C. Gates, Catal. Lett. 1994, 29, 235.

[151] V. Adeeva, J.W. de Haan, J. Jänchen, G.D. Lei, V. Schünemann, L.J.M. van de Ven, W.M.H. Sachtler, R.A. van Santen, J. Catal. 1995, 151, 364

[152] E.C. Sikabwe, M.A. Coelho, D.E. Resasco, R.L. White, Catal. Lett. 1995, 34, 23.

[153] J.E. Tábora, R.J. Davis, J. Chem. Soc., Faraday Trans. 1995, 91, 1825.

[154] K.T. Wan, C.B. Khouw, M.E. Davis, J. Catal. 1996, 158 , 311.

[155] R. Srinivasan, R.A. Keogh, A. Ghenciu, D. Fărcaşiu, B.H. Davis, J. Catal. 1996, 158, 502.

[156] M.A. Coelho, W.E. Alvarez, E.C. Sikabwe, R.L. White, D.E. Resasco, Catal. Today 1996, 28, 415.

[157] A.S. Zarkalis, C.-Y. Hsu, B.C. Gates, Catal. Lett. 1996, 37, 1.

[158] M. Benaïssa, J.G. Santiesteban, G. Diaz, M. José-Yacamán, Surf. Sci. 1996, 364, L591

[159] X. Song, K.R. Reddy, A. Sayari, J. Catal. 1996, 161, 206.

[160] C. Morterra, G. Cerrato, S. Di Ciero, M. Signorotto, A. Minesso, F. Pinna, G. Strukul, Catal. Lett. 1997, 49, 25.

[161] W.E. Alvarez, H. Liu, D.E. Resasco, Appl. Catal. A: General 1997, 162, 103

[162] A. Sayari, Y. Yang, X. Song, J. Catal. 1997, 167, 346.

[163] V. Adeeva, H.-Y. Liu, B.-Q. Xu, W.M.H. Sachtler, Topics Catal. 1998, 6, 61.

[164] S. Rezgui, A. Liang, T.-K. Cheung, B.C. Gates, Catal. Lett. 1998, 53,1 .

[165] F.C. Jentoft, Erdöl, Erdgas, Kohle 1998, 114, 441.

[166] S.X. Song, R.A. Kydd, Catal. Lett. 1998, 51, 95.

[167] D.R. Milburn, R.A. Keogh, D.E. Sparks, B.H. Davis, Appl. Surf. Sci. 1998, 126, 11.

[168] M. Scheithauer, E. Bosch, U.A. Schubert, H. Knözinger, T.K. Cheung, F.C. Jentoft, B.C. Gates, B. Tesche, J. Catal. 1998, 177, 137.

[169] T. Tanaka, T. Yamamoto, Y. Kohno, T. Yoshida, S. Yoshida, Jpn. J. Appl. Phys. 1999, 38, 30.

[170] A. Sayari, Y. Yang, J. Catal. 1999, 187, 186

[171] R.E. Jentoft, B.C. Gates, Catal. Lett. 2001, 72, 129.
[172] T.-K. Cheung, J.L. d'Itri, F.C. Lange, B.C. Gates, Catal. Lett. 1995, 31, 153.

[173] T.-K. Cheung, F.C. Jentoft, J.L. d'Itri, B.C. Gates, Chem. Engr. Sci. 1997, 52, 4607

[174] T.-K. Cheung, B.C. Gates, Topics in Catal. 1998, 6, 41, and references therein.

[175] A.S. Chelappa, R.C. Miller, W.J. Thomson, Appl. Catal. A. General 2001, 209, 359.

[176] A.H.P. Hahn, T. Ressler, U. Wild, R.E. Jentoft, F.C. Jentoft, in preparation.

[177] P. Li, I.W. Chen, J.E. Penner-Hahn, Phys. Rev. B 1993, 48, 10063, 10074 and 10082.

[178] J. Stöcker, R. Collongues, Compt. Rend. 1957, 245, 695

[179] H.J. Stöcker, Ann. Chim. 1960, 5, 1459.

[180] J. Stöcker, Bull. Soc. Chim. 1961, 78.

[181] M. Yashima, N. Ishizawa, M. Yoshimura, J. Am. Ceram. Soc. 1992, 75, 1541 and 1550.

[182] D. Das, H.K. Mishra, A.K. Dalai, K.M. Parida, Catal. Lett. 2004, 93, 185.

[183] B.S. Klose, F.C. Jentoft, R. Schlögl, I.R. Subbotina, V.B Kazansky, Langmuir 2005, 21, 10564

[184] X.-R. Chen, C.-L. Chen, N.-P. Xua, S. Han, C.-Y. Mou, Catal. Lett. 2003, 85, 177.

[185] X. Li, K. Nagaoka, J.A. Lercher, J. Catal. 2004, 227, 130.

[186] E.A. Garcia, M.A. Volpe, M.L. Ferreira, E.H. Rueda, Lat. Am. Appl. Res. 2005, 35, 281.

[187] K. Arata, H. Matsuhashi, M. Hino, H. Nakamura, Catal. Today 2003, 81, 17.

[188] C.J. Norman, P.A. Goulding, I. McAlpine, Catal. Today 1994, 20, 313.

[189] R. Srinivasan, D. Taulbee, B.H. Davis, Catal. Lett. 1991, 9, 1.

[190] S. Chokkaram, R. Srinivasan, D.R. Milburn, B.H. Davis, $J$. Colloid Interface Sci. 1994, 165, 160.

[191] T. Tatsumi, H. Matsuhashi, K. Arata, Bull. Chem. Soc. Jpn. 1996, 69, 1191.

[192] J. Livage, K. Doi, C. Mazières, J. Am. Ceram. Soc. 1968, 51,349 .

[193] A. Keshavaraja, N.E. Jacob, A.V. Ramaswamy, Thermochim. Acta 1995, 254, 267.

[194] B. Djuricic, S. Pickering, D. McGarry, P. Glaude, P. Tambuyser, K. Schuster, Ceram. Int. 1995, 21, 195.

[195] M. Sorrentino, L. Steinbrecher, F. Hazel, J. Colloid Interface Sci. 1969, 31, 307.

[196] R. Srinivasan, B. H. Davis, J. Colloid Interface Sci. 1993, 156, 400.

[197] K. Haberko, A. Ciesla, A. Pron, Ceram. Int. 1975, 1, 111.

[198] R. Srinivasan, M.B. Harris, S.F. Simpson, R.J. De Angelis, B.H. Davis, J. Mater. Res. 1988, 3, 787.

[199] P.D.L. Mercera, J.G. van Ommen, E.B.M. Doesburg, A.J. Burggraaf, J.R.H. Ross, Appl. Catal. 1990, 57, 127.

[200] I. Molodetsky, A. Navrotsky, M.J. Paskowitz, V.J. Leppert, S.H. Risbud, J. Non-Cryst. Solids 2000, 262, 106.

[201] S. Xie, E. Iglesia, A.T. Bell, Chem. Mater. 2000, 12, 2442

[202] I. Molodetsky, A. Navrotsky, M. Lajavardi, A. Brune, $Z$. Phys. Chem. 1998, 207, 59.

[203] Y. Murase, E. Kato, J. Am. Ceram. Soc. 1983, 66, 196.

[204] . Hahn, T. Ressler, R.E. Jentoft, F.C. Jentoft, Chem. Commun. 2001, 537 and electronic support information.

[205] A.H.P. Hahn, R.E. Jentoft, T. Ressler, G. Weinberg, R. Schlögl, F.C. Jentoft, J. Catal. 2005, 236, 324.

[206] J. Berzelius, J. Chem. Phys. (Schweigger, Nürnberg) 1812, 6,119 .

[207] J. Berzelius, Ann. Phys. (Gilbert, Leipzig) 1812, 42, 276. 
[208] J. Berzelius, J. Chem. Phys. (Schweigger, Nürnberg) 1818, $12,51$.

[209] R. Ruer, Z. Anorg. Allg. Chem. 1905, 43, 282.

[210] L. Wöhler, Koll.-Zeitschr. 1926, 38, 97.

[211] R.A. Keogh, R. Srinivasan, B.H. Davis, J. Catal. 1995, 151, 292.

[212] R.A. Comelli, C.R. Vera, J.M. Parera, J. Catal. 1995, 151, 96.

[213] B.H. Davis, Catal. Today 1994, 20, 219.

[214] C.R. Vera, J.M. Parera, J. Catal. 1997, 165, 254.

[215] C. Morterra, G. Cerrato, M. Signoretto, Catal. Lett. 1996, 41,101

[216] S.X. Song, R.A. Kydd, J. Chem. Soc. Faraday Trans. 1998, 94, 1333.

[217] F.C. Jentoft, B.C. Gates, unpublished results.

[218] A.V. Chadwick, G. Mountjoy, V.M. Nield, I.J.F. Poplett, M.E. Smith, J.H. Strange, M.G. Tucker, Chem. Mater. 2001, 13, 1219.

[219] X. Li, K. Nagaoka, L.J. Simon, R. Olindo, J.A. Lercher, Catal. Lett. 2007, DOI: 10.1007/s10562-006-9005-5.

[220] M. Hino, K. Arata, Chem. Lett. 1979, 482.

[221] T. Yamaguchi, T. Jin, K. Tanabe, J. Phys. Chem. 1986, 90 , 3148.
[222] I.J. Dijs, J.W. Geus, L.W. Jenneskens, J. Phys. Chem. B 2003, 107, 13403.

[223] C. Morterra, G. Cerrato, F. Pinna, M. Signoretto, J. Catal. 1995, 157, 109.

[224] M. Signoretto. F. Pinna, G. Strukul, G. Cerrato, C. Morterra, Catal. Lett. 1996, 36, 129.

[225] M. Hino, K. Arata, Catal. Lett. 1995, 30, 25.

[226] G. Larsen, L.M. Petkovic, Appl. Catal. A: General 1996, 148,155 .

[227] S. Vijay, E.E. Wolf, Appl. Catal. A: General 2004, 264, 117.

[228] M. Risch, E.E. Wolf, Appl. Catal. A: General 2001, 206, 283.

[229] S.Y. Kim, J.G. Goodwin Jr., D. Galloway, Catal. Today 2000, 63, 21

[230] C.R. Vera, J.C. Yori, C.L. Pieck, S. Irusta, J.M. Parera, Appl. Catal. A: General 2003, 240, 161.

[231] R.E. Jentoft, A.H.P. Hahn, F.C. Jentoft, T. Ressler, Phys. Chem. Chem. Phys. 2005, 7, 2830.

[232] S. Kuba, P. Concepción Heydorn, R.K. Grasselli, B.C. Gates, M. Che, H. Knözinger, Phys. Chem. Chem. Phys. 2001, 3, 146. 